\title{
PENENTUAN PESERTA LOMBA KOMPETENSI SISWA MENGGUNAKAN SIMPLE ADDITIVE WEIGHTING (SAW)
}

\author{
Maura Widyaningsih ${ }^{1)}$, Leo Giovanni ${ }^{2)}$ \\ Teknik Informatika, STMIK Palangkaraya \\ e-mail: maurawdya@gmail.com ${ }^{1)}$,maurawdya@gmail.com ${ }^{2)}$
}

\begin{abstract}
ABSTRAK
Penggunaan konsep dan metode merupakan salah satu faktor pendukung saat sebuah sistem diimplementasikan untuk menghasilkan suatu keputusan dari beberapa data yang akan diseleksi. Problem Lomba Kompetensi Siswa-Sekolah Menengah Kejuruan (LKS-SMK) adalah menyeleksi siswa-siswi terbaik dari seluruh pendaftar untuk dipilih dan diikutkan lomba. Hasil seleksi siswa akan dilakukan pembinaan oleh tim bidang kompetisi dan akan diikut sertakan pada kompetisi keahlian tingkat nasional. Dengan melibatkan sebuah metode, suatu sistem akan menghasilkan sebuah keputusan yang sesuai untuk penyeleksian data.

Metode untuk menentukan hasil seleksi adalah metode Simple Additive Weighting(SAW). Metode SAW merupakan metode dengan penjumlahan terbobot. Metode ini merupakan metode yang paling terkenal dan paling banyak digunakan dalam menghadapi situasi Multiple Attribute Decision Making (MADM). Dengan metode ini hasil seleksi diharapkan lebih ketat dan sesuai dengan kriteria yang ditetapkan.

Sistem mampu memberikan hasil rekomendasi keputusan yang tepat berdasarkan persyaratan yang telah ditetapkan. Informasi hasil perhitungan terhadap sejumlah data seleksi menunjukan pencapaian yang diharapkan, dalam waktu yang cepat dengan tidak melibatkan banyak user pengelola. Dengan demikian sistem ini dapat memberikan kemudahan pengelolaan untuk pelaksanaan seleksi lomba kompetensi siswa-sekolah menengah kejuruan (LKS-SMK) tingkat sekolah di Palangkaraya.
\end{abstract}

Kata Kunci: Penentuan Peserta Lomba, Lomba Kompetensi Siswa (LKS), Simple Additive Weighting (SAW)

\section{ABSTRACT}

The use of concepts and methods is one of the factors supporting a system to produce a decision of some of the data that will be selected. Competition Problem Competency Vocational High School Students (LKS-SMK) are selecting students all applicants to be selected and included race. Results of the selection of students will be developed by a team competition field will then be included in the national level competition expertise. By involving a method, a system will result in a decision that is appropriate for data selection.

Simple Additive weighting method (SAW) is a method for screening with a weighted summation. Yangpaling This method is a method widely used in situations of Multiple Attribute Decision Making (MADM). With this method of selection results are expected to be tight and in accordance with the criteria set.

The system is able to deliver results on the right decisions based on established criteria. Information on the calculation amount of data expected to show achievement in a short time, the user does not involve a lot of managers. Thus the system is able to provide ease of management for the implementation of selection competencies race-secondary vocational school students (LKS-vocational) school level in Palangkaraya.

Keywords: Participants determination Competition, Student Competency Competition (LKS), Simple Additive Weighting $(S A W)$

\section{PENDAHULUAN}

$\mathrm{P}$ eningkatan kinerja dalam institusi khususnya yang bergerak dibidang pendidikan, dapat dilihat dari informasi yang diterima masyarakat sesuai dengan aturan dan prinsip yang sesuai. Berangkat dari itu, pelaksanaan lomba kompetensi siswa sekolah menengah kejuruan (LKS-SMK) merupakan salah satu kasus yang dapat diangkat untuk diselesaikan secara komputerisasi dengan melibatkan metode dan konsep keputusan, sehingga hasilnya dapat diinformasikan ke masyarakat secara benar. Tujuan diadakannya LKS-SMK adalah untuk mengapresiasikan kemampuan dan kompetensi siswa, sebagai tolak ukur keberhasilan dalam pembelajaran, serta sebagai upaya memotivasi dan meningkatkan semangat belajar siswa. Siswa yang mengikuti LKS-SMK adalah siswa yang telah lolos seleksi di sekolah untuk mewakili daerahnya pada tingkat provinsi. LKS-SMK merupakan kompetisi tahunan antar siswa pada jenjang SMK sesuai bidang keahlian. Penelitian dilakukan di SMK Negeri 2 Palangkaraya, yang merupakan salah satu SMK ternama yang terdiri dari 3 jurusan keahlian yaitu Administrasi Perkantoran, Akuntansi, dan Penjualan/Pemasaran. Setiap tahun secara rutin SMK Negeri 2 mengikuti LKS-SMK tingkat Kota Palangkaraya. Lomba tersebut merupakan salah satu program pemerintah melalui Dinas Pendidikan Nasional untuk meningkatkan sumber daya manusia. Permasalahan yang sering dialami adalah banyaknya siswa dari berbagai jurusan yang mengikuti seleksi lomba kompetensi, sehingga dalam proses seleksi pelaksanaan 
menjadi kurang optimal dalam segi proses penilaian dan penentuan keputusan akhir.

Penggunaan konsep dan metode merupakan salah satu faktor pendukung saat diimplementasikan pada pengembangan sebuah sistem untuk menghasilkan suatu keputusan dari beberapa data. Proses seleksi akan menentukan rekomendasi beberapa siswa dari hasil penilaian, keputusan akhir akan diambil dari rangking siswa yang telah ditetapkan oleh pihak sekolah. Siswa yang masuk nominasi akan dilakukan pembinaan oleh tim bidang kompetisi dan akan diikut sertakan pada kompetisi keahlian tingkat nasional.

Metode yang digunakan dalam penelitian ini adalah metode Simple Additive Weighting (SAW). Metode SAW merupakan metode dengan penjumlahan terbobot [1]. Metode ini merupakan metode yang paling terkenal dan paling banyak digunakan dalam menghadapi situasi Multiple Attribute Decision Making (MADM). Dengan adanya sistem yang menggunakan metode SAW ini diharapkan mampu menyeleksi peserta lomba, sehingga dapat memberikan rekomendasi untuk diambil keputusan yang terbaik bagi siswa yang layak mewakili sekolah pada LKS-SMK tingkat provinsi. Hasil keputusan yang dikeluarkan oleh pihak sekolah akan memberikan informasi yang transparan dan diketahui kebenarannya dari perhitungan sistem.

Penggunaan beberapa metode terhadap dukungan keputusan pada sistem aplikasi telah banyak dilakukan oleh pengembang sistem dalam penelitiannya. Penelitian-penelitian yang terkait penggunaan metode untuk seleksi keputusan pada sekolah-sekolah, sehingga mendasari penulis mengangkat tema dengan data yang tersedia dengan metode yang dapat digunakan.

Sutikno dalam penelitiannya mengenai sistem pendukung keputusan (SPK) dengan metode Analytical Hierarkhi Process (AHP) untuk menentukan siswa SMA yang mengikuti olimpiade sains baik pada tingkat kabupaten, provinsi maupun nasional berbasis desktop. Kriteria-kriteria terdiri dari pengalaman olimpiade, intelegensi, kemampuan akademik, kemampuan olimpiade. Sistem yang dihasilkan dari masukan matrik berpasangan yang diberikan oleh user akan sangat berpengaruh terhadap tingkat dominasi/ prioritas dari kriteria yang satu terhadap kriteria yang lain [2].

Rustiyono, dkk dalam penelitiannya dengan metode AHP untuk peminatan jenjang dan jurusan pada siswa SMP Negeri 39 Semarang untuk melanjutkan ke SMA atau SMK. Kriteria-kriteria yang digunakan adalah minat, kemampuan, rencana setelah kerja. Subkriteria minat adalah pengetahuan, bahasa, teknologi, ekonomi, pertanian/ kelautan, kesehatan, dan kesenian. Subkriteria kemampuan adalah teori dan praktik. Subkriteria untuk rencana setelah kerja bekerja, berwirausaha, melanjutkan kuliah, atau menikah. Hasilnya adalah mempermudah bagi siswa dalam menentukan pilihan prioritas jenjang dan jurusan pendidikan berikutnya sehingga akan mendukung dalam proses pembelajaran yang sesuai dengan harapan orang tua, minat serta kemampuan siswa itu sendiri [3].

Usito dalam penelitiannya mengenai penilaian proses belajar mengajar menggunakan SAW berbasis desktop. Indikator kriteria penilaian yang digunakan adalah tingkat kehadiran mengajar, ketepatan memulai dan mengakhiri kuliah, ketepatan materi dan silabus, kemudahan penyampaian materi untuk dipahami, memotivasi belajar dalam mendalami mata kuliah, penggunaan ilustrasi/ alat bantu untuk memperjelas materi, melayani dan memberi perhatian dalam komunikasi dua arah, membantu, akomodatif, dan mudah untuk ditemui, memiliki pengetahuan aktual dalam pembelajaran. Hasil penelitian dapat mendukung keputusan pada penilaian proses belajar mengajar menggunakan kriteria yang telah ditentukan dan proses lain yang terkait dalam penilaian proses belajar mengajar [4].

\section{A. Decision Support System (DSS)}

\section{METODE}

DSS atau Sistem Pendukung Keputusan (SPK) merupakan sistem informasi interaktif yang dibangun untuk mendukung solusi atas suatu masalah atau untuk mengevaluasi suatu peluang. Aspek yang diperlukan untuk membuat sistem pendukung keputusan yaitu data, memberikan antar muka pengguna yang mudah dan dapat menggabungkan pemikiran pengambilan keputusan. Dapat disimpulkan bahwa sistem pendukung keputusan adalah sistem informasi berbasis komputer yang menggabungkan model dan data dalam upaya memecahkan masalah tidak terstruktur dengan keterlibatan pengguna yang ekstensif melalui tatap muka pengguna yang mudah digunakan [5].

\section{B. Metode Simple Additive Weighting (SAW)}

Menurut Fishburn 1967, dan MacCimmon 1968 metode Simple Additive Weighting (SAW) sering juga dikenal dengan istilah metode penjumlahan terbobot. Konsep dasar SAW adalah mencari penjumlahan terbobot dari rating kinerja dari setiap alternatif pada semua atribut. Metode SAW membutuhkan proses normalisasi matriks keputusan (X) ke suatu skala yang dapat diperbandingkan dengan semua rating alternatif yang ada [1].

Metode ini merupakan metode yang paling terkenal dan paling banyak digunakan dalam menghadapi situasi Multiple Attribute Decision Making (MADM). MADM itu sendiri merupakan suatu metode yang digunakan untuk mencari alternatif optimal dari sejumlah alternatif dengan kriteria tertentu. Persamaan untuk melakukan 
normalisasi tersebut adalah sebagai berikut:

$$
r_{i j}= \begin{cases}\frac{x_{i j}}{M a x_{i} x_{i j}} & , \text { jika } \mathrm{j} \text { adalah atribut keuntungan (benefit) } \\ \frac{x_{i j}}{\operatorname{Min}_{i} x_{i j}} & , \text { jika } \mathrm{j} \text { adalah atribut biaya (cost) }\end{cases}
$$

Dengan $r_{i j}$ adalah rating kinerja ternormalisasi dari alternatif $\left(A_{i}\right)$ pada atribut $C_{j} ; i=1,2, \ldots, m$ dan $j=1,2, \ldots, n$. Sedangkan nilai preferensi untuk setiap alternatif $\left(V_{i}\right)$ diberikan seperti yang ditunjukkan persamaan (2).

$$
V_{i}=\sum_{j=1}^{n} w_{j} r_{i j}
$$

Dengan:

$\mathrm{V}_{\mathrm{i}}=$ Nilai akhir dari alternatif

$\mathrm{w}_{\mathrm{j}}=$ Bobot yang telah ditentukan

$\mathrm{r}_{\mathrm{ij}}=$ Normalisasi matriks

$\mathrm{i}=$ Alternatif

$\mathrm{j}=$ Kriteria

$\mathrm{n}=$ Banyaknya kriteria

Nilai $V_{i}$ yang lebih besar mengindikasikan bahwa alternatif $\left(A_{i}\right)$ lebih terpilih.

Berikut ini adalah tahapan-tahapan menggunakan metode SAW:

a. Menentukan kriteria-kriteria yang akan dijadikan acuan dalam pengambilan keputusan, yaitu $C_{i}$.

b. Menentukan rating kecocokan setiap alternatif pada setiap kriteria.

c. Membuat matriks keputusan berdasarkan kriteria $\left(C_{l}\right)$, kemudian melakukan normalisasi matriks berdasarkan persamaan yang disesuaikan dengan jenis atribut sehingga diperoleh matriks ternormalisasi $R$.

d. Hasil akhir diperoleh dari proses perankingan yaitu penjumlahan dari perkalian matriks ternormalisasi $R$ dengan bobot vektor sehingga diperoleh nilai terbesar yang dipilih sebagai alternatif terbaik $\left(A_{I}\right)$ sebagai solusi.

\section{A. Pembobotan Nilai Kriteria}

\section{III.HASIL}

Pembobotan setiap kriteria merupakan penentuan prioritas nilai yang telah ditetapkan pada setiap alternatif persyaratan bagi setiap data siswa. Kriteria-kriteria yang digunakan sebagai persyaratan adalah peringkat rangking, nilai rata-rata raport, nilai uji kompetensi, nilai pelajaran, nilai etika siswa, hasil pengalaman LKS sebelumnya. Masing-masing kriteria memiliki subkriteria yang ditentukan berdasarkan rentang nilai penetapan, akan memberikan tingkat pembatasan data, sehingga penilaian akan lebih ketat dan tepat. Pemberian bobot nilai dari pendistribusian total $100 \%$ terhadap masing-masing kriteria didasarkan pada skala prioritas, sehingga hasil seleksi data akan lebih tepat dan sesuai dengan ketentuan. Hasil keputusan akan ditetapkan 5 rangking terdepan dari hasil rekomendai seluruh data peserta lomba.

TABEL I

\begin{tabular}{|c|c|c|c|c|}
\hline No & Kriteria & $\begin{array}{l}\text { Range } \\
\text { Nilai }\end{array}$ & Bobot $(\%)$ & Keterangan \\
\hline 1 & Peringkat Rangking & $1-5$ & 10 & $\begin{array}{l}1=\text { Sangat Baik; 2-3 = Baik } \\
4-5=\text { Cukup }\end{array}$ \\
\hline 2 & $\begin{array}{l}\text { Nilai Rata-rata } \\
\text { Raport }\end{array}$ & $10-100$ & 20 & $\begin{array}{l}85-100=A ; 65-84=B ; 58-64=C \\
40-57=D ; 0-39=E\end{array}$ \\
\hline 3 & Nilai Uji Kompetensi & $10-100$ & 30 & $\begin{array}{l}85-100=A ; 65-84=B ; 58-64=C \\
40-57=D ; 0-39=E\end{array}$ \\
\hline 4 & Nilai Pelajaran & $10-100$ & 24 & $\begin{array}{l}85-100=A ; 65-84=B ; 58-64=C \\
40-57=D ; 0-39=E\end{array}$ \\
\hline 5 & Nilai Etika Siswa & $10-100$ & 8 & $\begin{array}{l}76-100=\text { Sangat Baik; } 56-75=\text { Baik; } \\
36-55=\text { Cukup; } 10-35=\text { Kurang }\end{array}$ \\
\hline 6 & $\begin{array}{l}\text { Hasil Pengalaman } \\
\text { LKS Sebelumnya }\end{array}$ & $10-100$ & 8 & $\begin{array}{l}76-100=\text { Sangat Baik; } 56-75=\text { Baik; } \\
36-55=\text { Cukup; } 10-35=\text { Kurang }\end{array}$ \\
\hline & Total & & $100 \%$ & \\
\hline
\end{tabular}

TABEL PEMBOBOTAN KRITERIA

Setiap data yang akan diperhitungkan memiliki nilai kriteria dengan bobot yang berbeda berdasarkan ketentuan seperti yang ditunjukan pada Tabel I. Sehingga data-data tersebut akan mudah diperhitungkan dengan perhitungan SAW, dan secara otomatis sistem akan memberikan hasil nilai masing-masing data. Dengan mengambil nilai terbesar dari urutan 1 sampai dengan 5 merupakan hasil keputusan akhir peserta lomba. Penentuan Tabel pembobotan dari setiap kriteria dapat dilihat pada Tabel I. 


\section{B. Pemrosesan SAW}

Gambar 1 menggambarkan proses keseluruhan dari sistem ini dan menggambarkan proses metode SAW. Data calon peserta terdiri dari NIS, nama siswa, jenis kelamin, tempat lahir,kelas, dan alamat siswa.

Pada Gambar 1.(a) merupakan diagram yang menggambarkan proses keseluruhan seleksi calon peserta lomba kompetensi siswa. Data peserta akan diolah dan diperhitungkan dengan metode SAW, hasilnya adalah rekomendasi keputusan calon peserta lomba. Hasil rekomendasi akan ditentukan keputusan berdasarkan 5 ranking terbesar untuk peserta lomba.

Gambar 1.(b) menggambarkan tahapan proses pada metode SAW yang diolah data-datanya berdasarkan kriteria tertentu. Kriteria data yang dimasukan adalah peringkat rangking, nilai rata-rata raport, nilai uji kompetensi, nilai pelajaran, nilai etika, dan hasil pengalaman LKS sebelumnya.

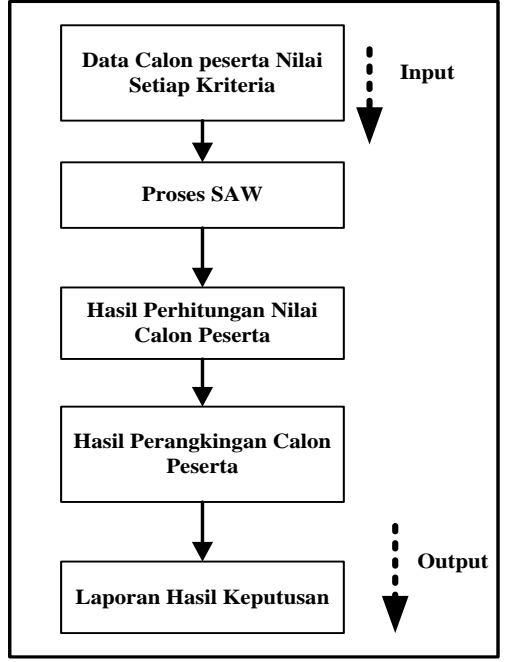

(a) Proses Sistem Keseluruhan

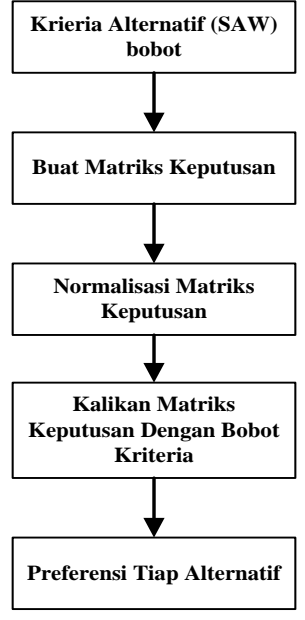

(b) Proses Metode SAW

Gambar 1. Diagram proses seleksi LKS_SMK dengan metode SAW

Data-data peserta dengan nilai pada masing-masing kriteria yang masuk, semuanya akan ditentukan hasilnya melalui proses perhitungan dengan SAW. Pada tahapan SAW data-data yang memiliki nilai kriteria, akan dilakukan perhitungan normalisasi data dengan menggunakan persamaan (1). Kemudian hasilnya akan dilakukan perkalian dengan pembobotan pada setiap kriteria berdasarkan persamaan (2). Selanjutnya akan diurutkan dari nilai terbesar ke terkecil, sehingga keputusan akan diambil 5 rangking terbesar dari seluruh data yang memenuhi persyaratan.

\section{Rancangan Sistem}

Data flow diagram (DFD) adalah alat pembuatan model yang memungkinkan profesional sistem untuk menggambarkan sistem sebagai suatu jaringan proses fungsional yang dihubungkan satu sama lain dengan alur data, baik secara manual maupun komputerisasi.

\section{Context Diagram}

Gambaran sistem secara keseluruhan berupa Context Diagram yang ditunjukkan pada Gambar 2. Data-data yang dikelola oleh sistem adalah data user, data siswa, data kriteria, data nilai.

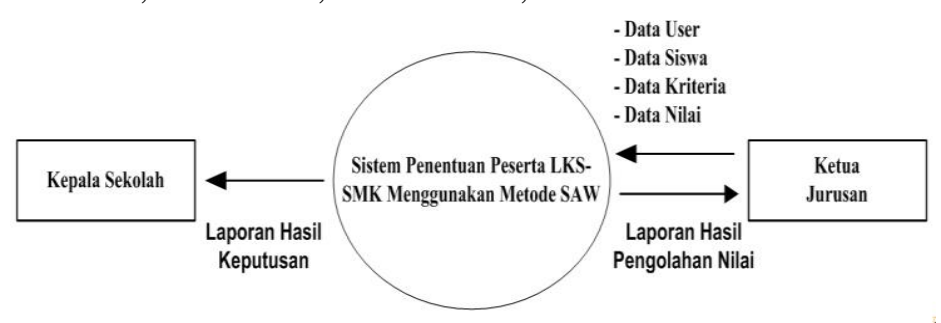

Gambar 2. Context diagram sistem penentuan peserta LKS-SMK

User yang mengelola dan menggunakan sistem ada dua yaitu Ketua jurusan dan Kepala Sekolah. Ketua jurusan memiliki peranan untuk mengelola data-data yang dimasukkan, dan menerima laporan hasil rekomendasi, sedangkan hasil keputusan akan diinformasikan ke Kepala Sekolah. 
DFD Level 0

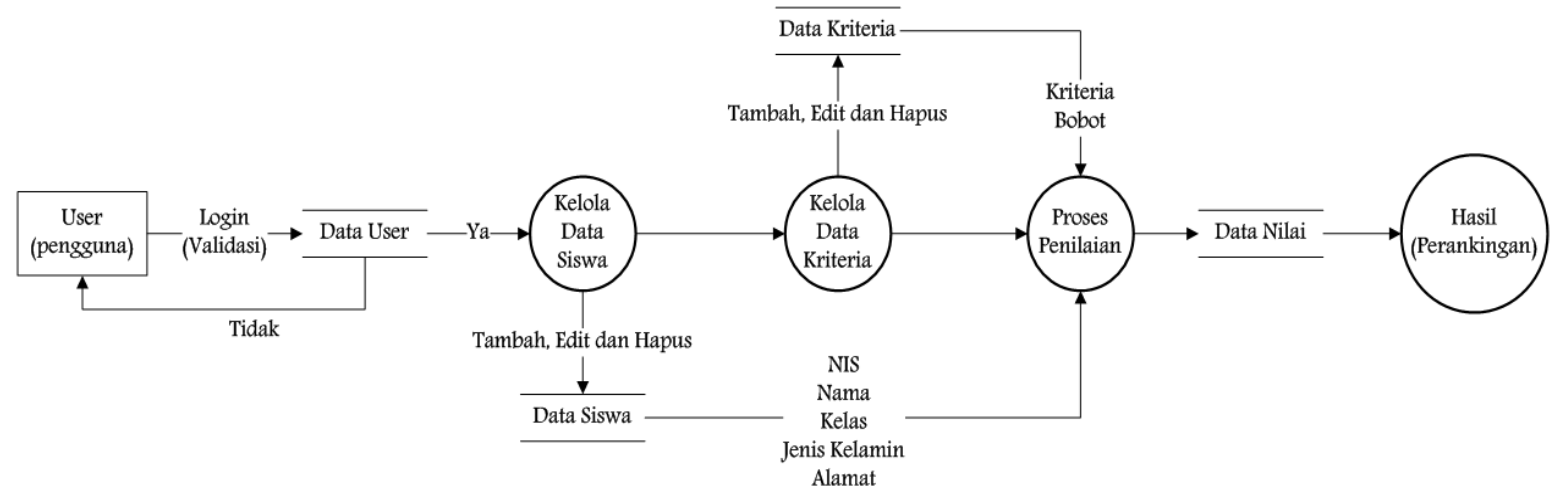

Gambar 3. DFD Level 0 Sistem Penentuan Peserta LKS-SMK menggunakan Metode SAW

DFD Level 1 Proses Data Kriteria

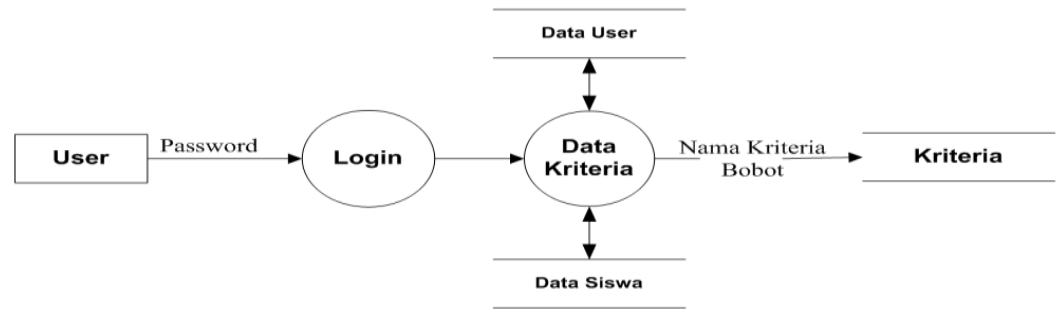

Gambar 4. DFD Level 1 Proses Data Kriteria

Entity Relation Diagram (ERD)

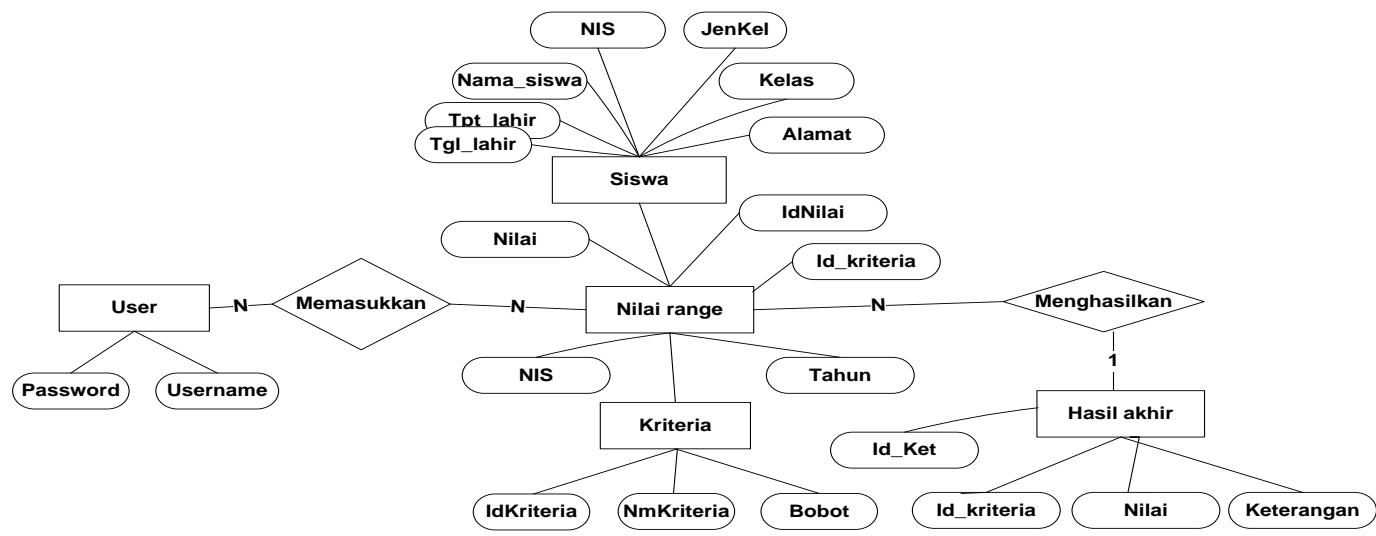

Gambar 5. ERD Penentuan Peserta LKS-SMK menggunakan Metode SAW

\section{PEMBAhasan}

Data-data peserta pada penelitian ini diambil dari siswa peserta LKS - SMK Negeri 2 Palangkaraya tahun 2015. Sistem menyediakan beberapa interface yang akan digunakan dan dikelola oleh user. Tahapan awal sistem seleksi adalah memasukan hak akses user, hal ini demi keamanan dari penggunaan sistem untuk tidak disalahgunakan. Gambar 6. Interface Login pada sistem

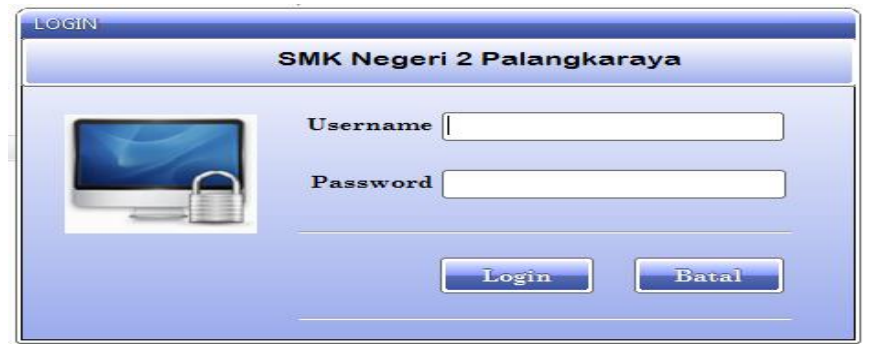




\section{E. Implementasi Sistem}

Keamanan sistem diperlukan demi perlindungan dari orang-orang yang tidak diberikan hak untuk menggunakannya. Login awal diperlukan untuk user tertentu mengelola dan mengolah sistem, jika Username dan Password diisikan tidak benar, maka tidak akan dapat masuk kesistem menu utama, namun jika berhasil akan masuk ke menu utama seperti ditunjukkan pada Gambar 6.

Antarmuka awal sistem berjalan seperti yang ditunjukkan pada Gambar 7 memuat beberapa menu yang dapat diakses oleh user. Menu-menu tersebut berupa menu Master Data, Penilaian, Laporan, dan Sistem. Menu Master Data digunakan untuk mengelola data peserta lomba. Menu Penilaian digunakan untuk melakukan pengelolaan kriteria. Menu Laporan digunakan untuk menampilkan hasil seleksi peserta lomba.

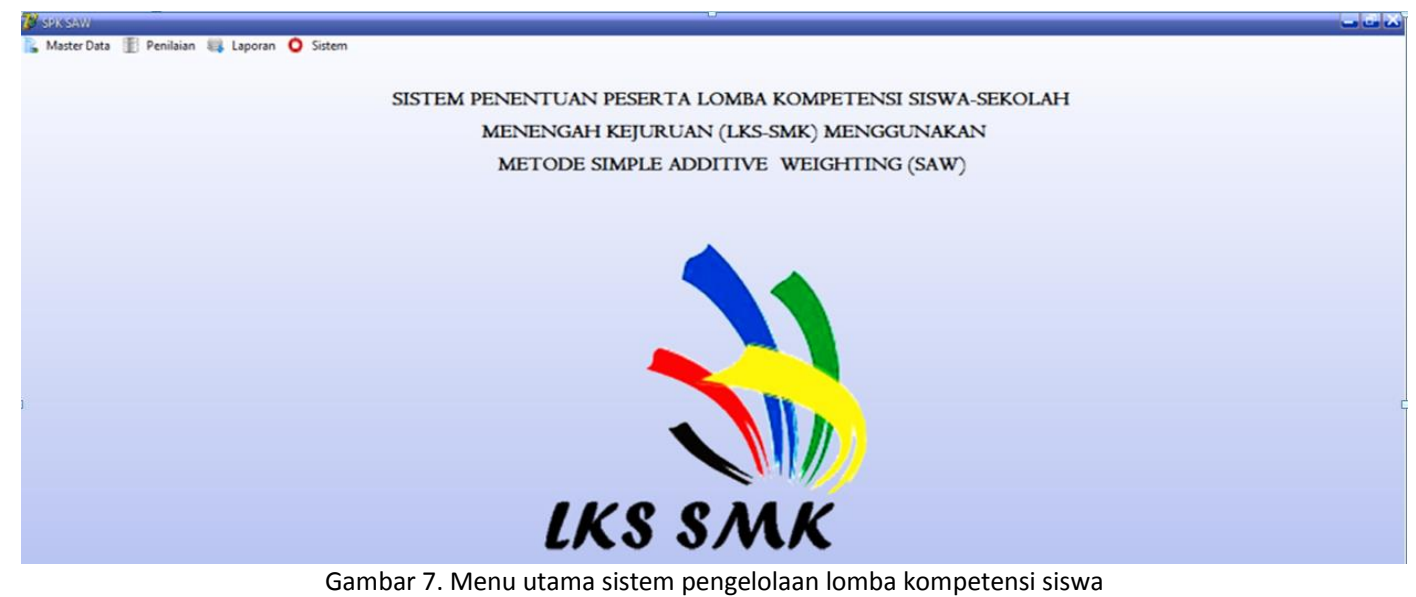

Pada form data siswa, user dapat mengelola input data siswa, yang dilengkapi dengan fasilitas tombol simpan, hapus, perbaharui, batal, cari dan ubah. Gambar 8 merupakan antarmuka untuk pengelolaan data calon peserta siswa yang ikut lomba kompetensi.

\begin{tabular}{|c|c|c|c|c|c|c|c|}
\hline \multicolumn{8}{|c|}{ Search... } \\
\hline & NIS & Nama Siswa & Kelamin & Tempat Lahir & Tgl Lahir & Kelas & Alamat \\
\hline 1 & 8290 & Yuliana & Perempuan & Palangkaraya & 02/01/1998 & XII & Jl. Antang Kalang I \\
\hline 2 & 8299 & Andriana & Perempuan & Palangkaraya & $16 / 05 / 1998$ & XII & Jl. Ahmad Yani \\
\hline 3 & 8300 & Tirza F.Z & Perempuan & Palangkaraya & $15 / 10 / 1999$ & $x$ & Jl. Temanggung Tilung II \\
\hline 4) & 8313 & Nurul Huda Efendy & Perempuan & Palangkaraya & $14 / 09 / 1999$ & $x$ & Jl. Temanggung Jayakarti \\
\hline
\end{tabular}

Gambar 8. Antarmuka pengelolaan data peserta lomba kompetensi siswa

Antarmuka pada Gambar 9 digunakan untuk mengelola kriteria-kriteria yang diperlukan untuk menentukan peserta lomba LKS. Pada form kriteria terdapat 3 tombol kelola yang dapat digunakan yaitu tombol Tambah, Ubah, dan Hapus kriteria.

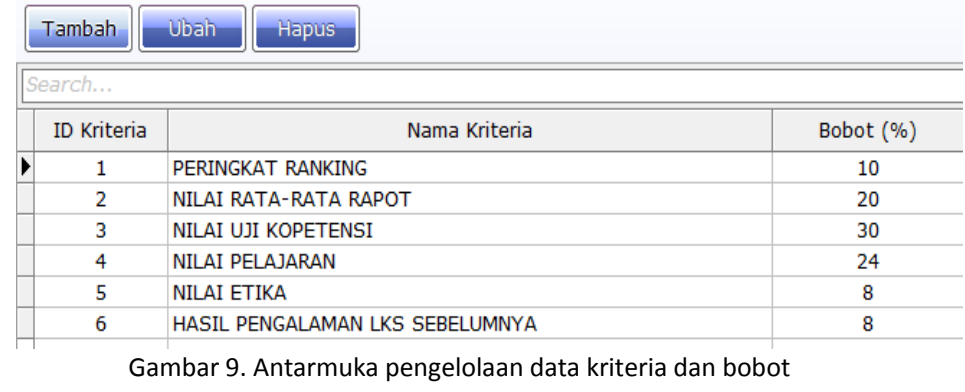

Pada form laporan akan menampilkan hasil keputusan seleksi lomba, dengan fasilitas penentuan tahun / periode data seleksi yang akan ditampilkan. Hasilnya akan dirangking secara langsung dalam 4 besar dan dapat dilakukan proses pencetakan dengan menekan tombol cetak. Gambar 10 menunjukkan antarmuka hasil seleksi peserta LKS. 


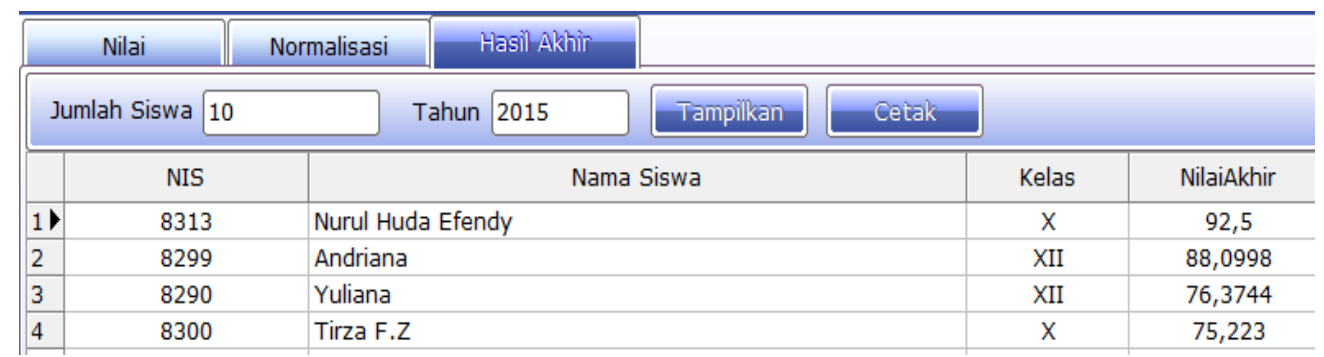

\begin{tabular}{|}
$\begin{array}{l}\text { Laporan Hasil Rekomendasi Sistem Pendukung Keputus an } \\
\text { Penentuan Peserta LKS - SMK } \\
\text { SMK Negeri 2 Palangkaraya } \\
\text { Tahun Penilaian 2015 }\end{array}$ \\
\hline \begin{tabular}{|c|l|l|c|c|}
\hline \\
Ranking
\end{tabular} & Nama Sis wa & Kelas & Nilai Akhir \\
\hline 1 & 13013 & Yogi & $\mathrm{XI}$ & 98.8095 \\
\hline 2 & 13014 & Vero & $\mathrm{X}$ & 95.7143 \\
\hline 3 & 13011 & Veri & $\mathrm{XI}$ & 85.0833 \\
\hline 4 & 13012 & Ando & & 80.7319 \\
\hline
\end{tabular}

Gambar 10. Antarmuka hasil seleksi peserta lomba LKS

\section{F. Implementasi Hitungan}

Sebagai contoh implementasi SAW pada 4 data siswa dengan perhitungan manual yang akan dilakukan perbandingan dengan perhitungan sistem. Ada 4 data siswa yaitu Yuliana $\left(A_{l}\right)$, Andriana $\left(A_{2}\right)$, Tirza F.Z $\left(A_{3}\right)$, Nurul Huda Efendy $\left(A_{4}\right)$. Untuk keenam kriteria peringkat rangking $\left(C_{1}\right)$, nilai rata-rata raport $\left(C_{2}\right)$, nilai uji kompetensi $(C 3)$, nilai pelajaran $(C 4)$, nilai etika $\left(C_{5}\right)$, hasil pengalaman LKS sebelumnya $\left(C_{6}\right)$. Untuk bobot $(\mathrm{W})$ berdasarkan pada Tabel II.

TABEL II.

TABEl DATA KRITERIA SISWA DAN BOBOT

\begin{tabular}{ccccccc}
\hline \hline & C1 & C2 & C3 & C4 & C5 & C6 \\
\hline $\mathbf{A 1}$ & 3 & 70 & 70 & 65 & 45 & 40 \\
$\mathbf{A 2}$ & 2 & 70 & 79 & 80 & 76 & 70 \\
$\mathbf{A 3}$ & 4 & 69 & 69 & 60 & 30 & 40 \\
$\mathbf{A 4}$ & 1 & 85 & 89 & 80 & 76 & 70 \\
$\mathbf{W}$ & 10 & 20 & 30 & 24 & 8 & 8 \\
\hline \hline
\end{tabular}

Matriks keputusan dibentuk dari nilai-nilai kriteria data siswa, sebagai contoh seperti yang telah ditentukan berdasarkan pada Tabel I sebelumnya.

$$
X=\left\{\begin{array}{llllll}
3 & 70 & 70 & 65 & 45 & 70 \\
2 & 70 & 79 & 80 & 76 & 70 \\
4 & 69 & 70 & 60 & 30 & 40 \\
1 & 85 & 89 & 80 & 76 & 70
\end{array}\right\}
$$

Normalisasi Matriks $X$ :

$$
\begin{array}{ll}
r_{11}=\frac{3}{\max \{3 ; 2 ; 4 ; 1\}}=\frac{3}{4}=0,75 & r_{24}=\frac{80}{\max \{65 ; 80 ; 60 ; 80\}}=\frac{80}{80}=1,00 \\
r_{21}=\frac{2}{\max \{3 ; 2 ; 4 ; 1\}}=\frac{2}{4}=0,5 & r_{34}=\frac{60}{\max \{65 ; 80 ; 60 ; 80\}}=\frac{60}{80}=0,75 \\
r_{31}=\frac{4}{\max \{3 ; 2 ; 4 ; 1\}}=\frac{4}{4}=1,00 & r_{44}=\frac{80}{\max \{65 ; 80 ; 60 ; 80\}}=\frac{80}{80}=1,00 \\
r_{41}=\frac{1}{\max \{3 ; 2 ; 4 ; 1\}}=\frac{1}{4}=0,25 & r_{15}=\frac{45}{\max \{45 ; 76 ; 30 ; 76\}}=\frac{45}{76}=0,59 \\
r_{I 2}=\frac{70}{\max \{70 ; 70 ; 69 ; 85\}}=\frac{70}{85}=0,82 & r_{25}=\frac{76}{\max \{45 ; 76 ; 30 ; 76\}}=\frac{76}{76}=1,00 \\
r_{22}=\frac{70}{\max \{70 ; 70 ; 69 ; 85\}}=\frac{70}{85}=0,82 & r_{35}=\frac{30}{\max \{45 ; 76 ; 30 ; 76\}}=\frac{30}{76}=0,39 \\
r_{32}=\frac{69}{\max \{70 ; 70 ; 69 ; 85\}}=\frac{69}{85}=0,81 & r_{45}=\frac{76}{\max \{45 ; 76 ; 30 ; 76\}}=\frac{76}{76}=1,00
\end{array}
$$




$$
\begin{aligned}
& r_{42}=\frac{85}{\max \{70 ; 70 ; 69 ; 85\}}=\frac{85}{85}=1,00 \\
& r_{13}=\frac{70}{\max \{70 ; 79 ; 69 ; 89\}}=\frac{70}{89}=0,79 \\
& r_{23}=\frac{79}{\max \{70 ; 79 ; 69 ; 89\}}=\frac{79}{89}=0,89 \\
& r_{33}=\frac{69}{\max \{70 ; 79 ; 69 ; 89\}}=\frac{69}{89}=0,78 \\
& r_{14}=\frac{65}{\max \{65 ; 80 ; 60 ; 80\}}=\frac{65}{80}=0,81 \\
& r_{43}=\frac{89}{\max \{70 ; 79 ; 69 ; 89\}}=\frac{89}{89}=1,00
\end{aligned}
$$

$$
\begin{aligned}
& r_{16}=\frac{40}{\max \{40 ; 70 ; 40 ; 70\}}=\frac{40}{70}=0,57 \\
& r_{26}=\frac{70}{\max \{40 ; 70 ; 40 ; 70\}}=\frac{70}{70}=1,00 \\
& r_{36}=\frac{40}{\max \{40 ; 70 ; 40 ; 70\}}=\frac{40}{70}=0,57 \\
& r_{46}=\frac{70}{\max \{40 ; 70 ; 40 ; 70\}}=\frac{70}{70}=1,00
\end{aligned}
$$

Dari hasil perhitungan diatas maka didapat matriks ternomalisasi $R$

\begin{tabular}{|c|c|c|c|c|c|c|c|c|}
\hline NIS & Nama Siswa & kelas & PERINGKAT RANKING I & RAT/ & ETENI & ARAN & TIKA & \\
\hline | 8290 & Yuliana & XII & 3 & 70 & 70 & 65 & 45 & 40 \\
\hline 8299 & Andriana & XII & 2 & 70 & 79 & 80 & 76 & 70 \\
\hline 8300 & Tirza F.Z & $x$ & 4 & 69 & 69 & 60 & 30 & 40 \\
\hline 8313 & Nurul Huda Efendy & $x$ & 1 & 85 & 89 & 80 & 76 & 70 \\
\hline
\end{tabular}

$$
X=\left\{\begin{array}{lccccc}
0,75 & 0,82 & 0,79 & 0,81 & 0,59 & 0,57 \\
0,5 & 0,82 & 0,89 & 1,00 & 1,00 & 1,00 \\
1,00 & 0,81 & 0,78 & 0,75 & 0,39 & 0,57 \\
0,25 & 1,00 & 1,00 & 1,00 & 1,00 & 1,00
\end{array}\right]
$$

Proses selanjutnya adalah perkalian dengan bobot dari masing-masing kriteria untuk menghasilkan rekomendasi keputusan.

$$
W=\{10 ; 20 ; 30 ; 24 ; 8 ; 8\}
$$

Hasil yang diperoleh sebagai berikut:

$$
\begin{aligned}
& V_{l}=(10)(0,75)+(20)(0,82)+(30)(0,79)+(24)(0,81)+(8)(0,54)+(8)(0,57)=76,37 \\
& V_{2}=(10)(0,5)+(20)(0,82)+(30)(0,89)+(24)(1,00)+(8)(1,00)+(8)(1,00)=88,09 \\
& V_{3}=(10)(1,00)+(20)(0,81)+(30)(0,78)+(24)(0,75)+(8)(0,39)+(8)(0,57)=75,22 \\
& V_{4}=(10)(0,25)+(20)(1,00)+(30)(1,00)+(24)(1,00)+(8)(1,00)+(8)(1,00)=92,5
\end{aligned}
$$

Hasil hitungan dengan SAW terhadap keempat data siswa, maka dapat ditentukan urutan nilai akhir dari yang besar ke kecil yaitu Nurul Huda Efendy $\left(V_{4}\right)$, Andriana $\left(V_{2}\right)$, Yuliana $\left(V_{l}\right)$, Tirza F.Z $\left(V_{3}\right)$. Berikut merupakan hasil implementasi pada sistem, Gambar 11 menunjukkan data-data siswa yang dimasukan nilainya perkriteria.

Sedangkan Gambar 12 merupakan hasil normalisasi data $(R)$.

\begin{tabular}{|l|l|r|r|r|r|r|r|r|}
\hline NIS & Nama Siswa & PERINGKAT RANKING & NILAI RATA-RATA NilAi UJI KOPETENSI NILAI PELAJARAn NILAI ETIKA HASIL PENGALAMAN \\
\hline 8290 & Yuliana & 0,75 & 0,82 & 0,79 & 0,81 & 0,59 & 0,57 \\
\hline 8299 & Andriana & 0,5 & 0,82 & 0,89 & 1 & 1 & 1 \\
\hline 8300 & Tirza F.Z & 1 & 0,81 & 0,78 & 0,75 & 0,39 & 0,57 \\
\hline 8313 & Nurul Huda Efendy & 0,25 & 1 & 1 & 1 & 1 & 1 \\
\hline
\end{tabular}

\begin{tabular}{|c|c|l|c|c|}
\hline & NIS & Nama Siswa & Kelas & Nilaiakhir \\
\hline 1 & 8313 & Nurul Huda Efendy & X & 92,5 \\
\hline 2 & 8299 & Andriana & XII & 88,0998 \\
\hline 3 & 8290 & Yuliana & XII & 76,3744 \\
\hline 4 & 8300 & Tirza F.Z & X & 75,223 \\
\hline
\end{tabular}

Gambar 13. Hasil perkalian matriks normalisasi (R) dengan bobot (w)

Gambar 13 menunjukkan hasil perkalian normalisasi data $(R)$ dengan bobot $(w)$ sehingga diperoleh nilai akhir. Dari hasil nilai akhir inilah dapat ditentukan hasil rekomendasi siswa, sehingga dapat diputuskan hasil seleksi LKS dengan mengambil rangking yang ditetapkan. Dari hasil perhitungan tersebut dapat disimpulkan bahwa dengan 
perhitungan manual dan perhitungan menggunakan sistem telah menghasilkan hasil yang sama yaitu peringkat 1 diperoleh oleh Nurul Huda Effendy, peringkat 2 diperoleh oleh Andriana, peringkat 3 diperoleh oleh Yuliana dan peringkat 4 diperoleh oleh Tirza.

\section{A. Simpulan}

\section{SIMPULAN DAN SARAN}

Kesimpulan yang dapat diambil dari penelitian ini adalah sebagai berikut:

1) Sistem yang dibuat mampu memberikan hasil rekomendasi keputusan yang sesuai, berdasarkan kriteriakriteria peringkat rangking, nilai rata-rata raport, nilai uji kompetensi, nilai pelajaran, nilai etika, hasil pengalaman LKS sebelumnya.

2) Informasi hasil perhitungan sejumlah data menunjukan pencapaian yang diharapkan dalam waktu yang cepat, dengan tidak perlu melibatkan banyak user pengelola. User memiliki hak akses untuk mengelola sistem.

3) Sistem memberikan ketersediaan untuk menambah kriteria dan merubah bobot tiap kriteria sehingga memberikan peluang pengelola sistem untuk melakukan pembaharuan.

\section{B. Saran}

Saran yang dapat diambil dari penelitian ini adalah sebagai berikut:

1) Sistem dapat dikembangkan dengan menggunakna metode Sistem Pendukung Keputusan yang lain, ataupun hibrit beberapa metode SPK.

2) Sistem dapat dikombinasikan atau dikembangkan dengan metode Fuzzy dan Jaringan Syaraf Tiruan.

3) Sistem dapat dikembangkan berbasis jaringan atau web, jika pengelolaan dibutuhkan banyak user, ataupun diinformasikan ke banyak orang.

4) Metode dapat diterapkan pada permasalahan keputusan selain dari LKS.

\section{REFERENSI}

[1] S. Kusumadewi, S. Hartati, A. Harjoko, dan R. Wardoyo, Fuzzy multi-attribut decision making (fuzzy MADM), Graha Ilmu, Yogyakarta, 2006.

[2] Sutikno, "Sistem pendukung keputusan metode ahp untuk pemilihan siswa dalam mengikuti olimpiade sains di sekolah menengah atas", Program Studi Ilmu Komputer FMIPA UNDIP, e_journal UNDIP, ISSN 978-602-97737-0-5, 2010.

[3] M. E. Rustiyono, Pujiono, A. Fahmi, "Rancangan sistem pendukung keputusan peminatan jenjang dan jurusan dengan menggunakan metode analytical hierarchy process (studi kasus pada siswa SMP Nnegeri 39 Semarang)”, Universitas Dian Nuswantoro, Jurnal Techno, vol. 13, no. 4, pp. 222-231, 2014.

[4] N. J. Usito, "Sistem pendukung keputusan penilaian proses belajar mengajar menggunakan metode simple additive weighting (saw)", Tesis Pasca Sarjana Universitas Diponegoro Semarang, 2013.

[5] Kusrini, Konsep dan aplikasi sistem pendukung keputusan, CV. Andi Offset, Yogyakarta, 2007. 